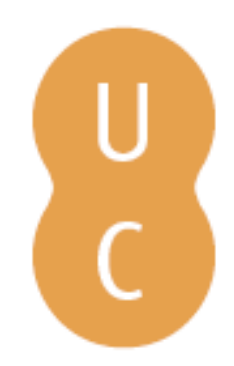

\title{
nombalina
}

\section{Burnt severity and satellite data: a first approach in the ornemental vegetation in wildland urban interface}

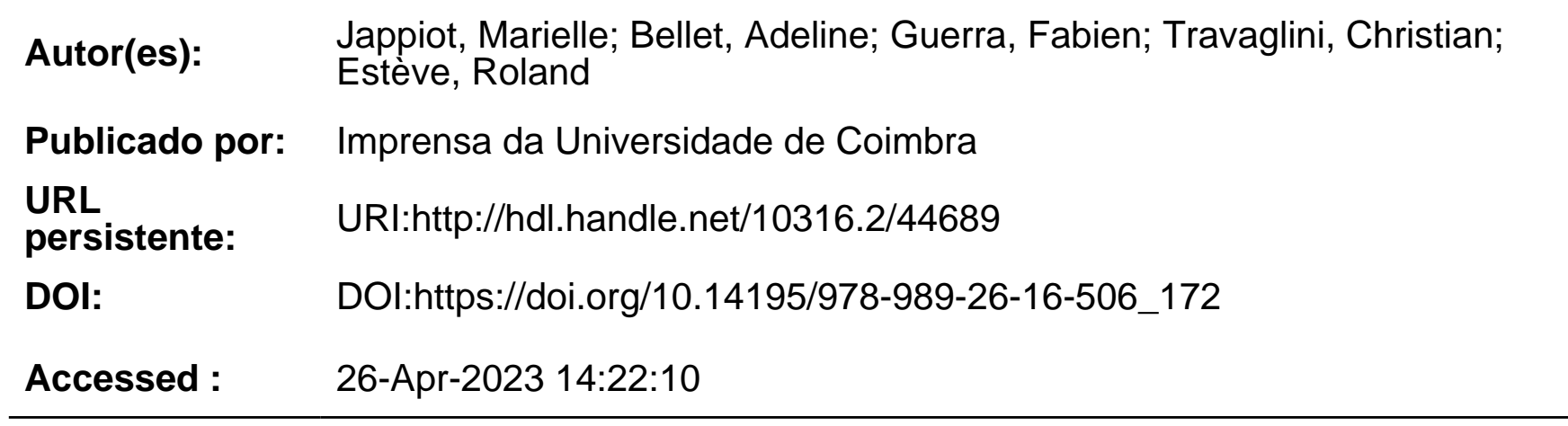

A navegação consulta e descarregamento dos títulos inseridos nas Bibliotecas Digitais UC Digitalis, UC Pombalina e UC Impactum, pressupõem a aceitação plena e sem reservas dos Termos e Condições de Uso destas Bibliotecas Digitais, disponíveis em https://digitalis.uc.pt/pt-pt/termos.

Conforme exposto nos referidos Termos e Condições de Uso, o descarregamento de títulos de acesso restrito requer uma licença válida de autorização devendo o utilizador aceder ao(s) documento(s) a partir de um endereço de IP da instituição detentora da supramencionada licença.

Ao utilizador é apenas permitido o descarregamento para uso pessoal, pelo que o emprego do(s) título(s) descarregado(s) para outro fim, designadamente comercial, carece de autorização do respetivo autor ou editor da obra.

Na medida em que todas as obras da UC Digitalis se encontram protegidas pelo Código do Direito de Autor e Direitos Conexos e demais legislação aplicável, toda a cópia, parcial ou total, deste documento, nos casos em que é legalmente admitida, deverá conter ou fazer-se acompanhar por este aviso.

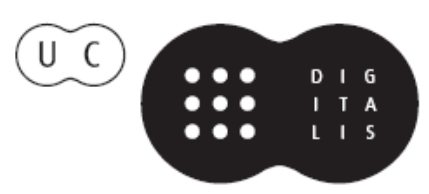




\section{ADVANCES IN}

\section{FOREST FIRE RESEARCH}

\section{8}

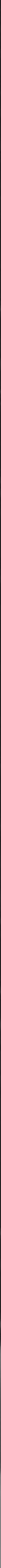


Short contribution - Fire at the Wildland Urban Interface

Burnt severity and satellite data: a first approach in the ornemental vegetation in wildland urban interface

\author{
Marielle Jappiot *; Adeline Bellet; Fabien Guerra; Christian Travaglini; Roland Estève \\ IRSTEA. EMR, Mediterranean Ecosystem and Risks, 3275 Route de Cézanne, CS40061, 13182 Aix-en- \\ Provence Cedex 5, \{marielle.jappiot@irstea.fr*, adeline.bellet@irstea.fr, fabien.guerra@irstea.fr \\ ,christian.travaglini@irstea.fr,roland.esteve@irstea.fr\}
}

Keywords: fire, burnt severity, damage, remote sensing, Sentinel, wildland urban interface

\title{
1. Introduction
}

When a fire occurs, the knowledge on its location and the burnt area allows calculating economic loss, observing the impact on the environment, and modeling landscape evolution (Gitas et al., 2007). Fire severity assessment allows predicting post fire vegetation dynamics, and anticipating soil erosion (Allen and Sorbel, 2008). It also provides data for fire assessment models by giving information on fire frequency and fire intensity. An exhaustive knowledge of the past fires on a landscape, allows validating and improving those fire risk models.

Database on past fires are not fulfilled systematically with georeferenced contours. When contours are available, these are generally fires larger than 50 ha. Indeed, large fires causing damage to buildings are generally very well described: contours are made from satellite images available quickly, with field checks at the margin. For fires $<50$ ha, there is no rule for the systematic collection of information. In fact, databases are heterogeneous from one department to another. However, knowledge on these "small fires" is important, especially since they often occur in wildland urban interface (WUI) areas where forest fire risk management poses particular problems. With the aim of building accurate and comprehensive fire history databases, satellite imagery is a very interesting source of information as it provides information on vegetation over large areas.

\section{Objectives}

We will use the complementarity of these different satellite sources (spatial and temporal resolution, different wavelength channels) to develop a method of fire severity mapping. Severity levels were related to levels of damage observed in the field. Damage assessment methods based on vegetation indices and before / after event image comparisons were developed to characterize the severity of fires. However, there are few studies on fire behavior in the ornemental vegetation, and none on the characterization of the damage in WUI, which requires the development of a specific methodology. It is a first approach that is developed here.

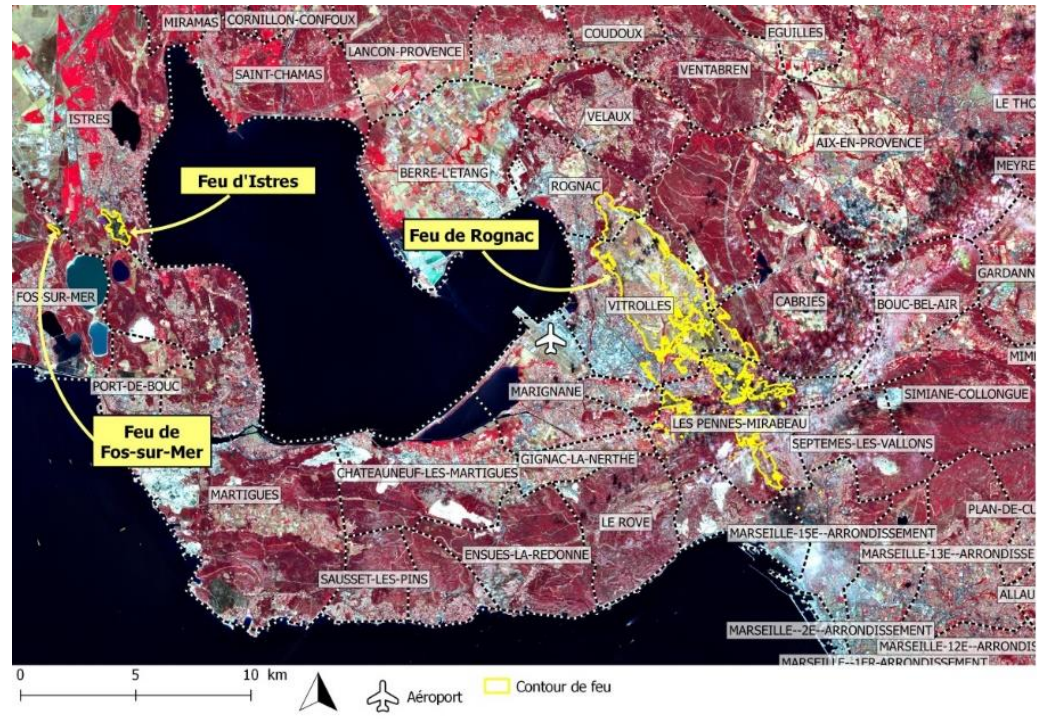

Figure 1 - Location map of the past fires. Source image Sentinel 2, Données Copernicus Sentinel-2 2017 traitées au niveau 2A par le Cnes pour le centre de données Theia 


\section{Material and methods}

The study area is situated in southern France, and focused on three past fire (Fig. 1).

In France, within the framework of the THEIA data center (www.theia-land.fr), the GEOSUD team aims to develop a national satellite imagery infrastructure for environmental and landscape research, and its applications to management and public policies. This scientific and technical structure aims to facilitate the use of these images. Thus, the Pleiades and SPOT6 / 7 images are available for research as well as Sentinel-2 images.

For this study, several complementary satellite sources were used on 3 fires in the south of France: Rognac 2016, Fos 2017 and Istres 2017, of variable size, which affected the WUIs

Damage surveys were carried out in the field, in the natural zone and in the interface zone, adapting the protocol. Scores of damage were calculated. Vegetation indices were calculated from satellite data, including Gdnvi which has been classified in severity level. The indices were then correlated to the field scores.

Fig 2. Gives an illustration of the plots (yellow) in the WUI.

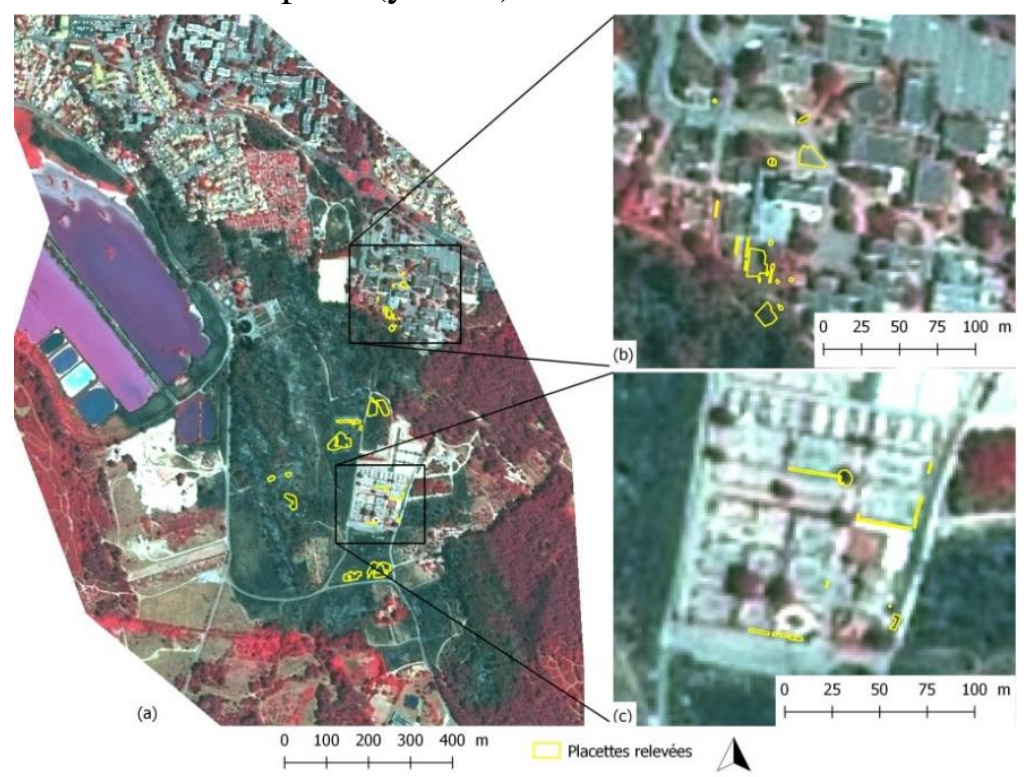

Figure 2 - Plots on the Istres Fire. a : General map of the fire ; $b$ : location 1 ; $c$ : location 2. Source image : SPOT 6 (C) AIRBUS DS 2017

\section{First results}

Ornemental vegetation is precisely geolocalized on Pleiades, and SPOT6 as well (Fig 3).

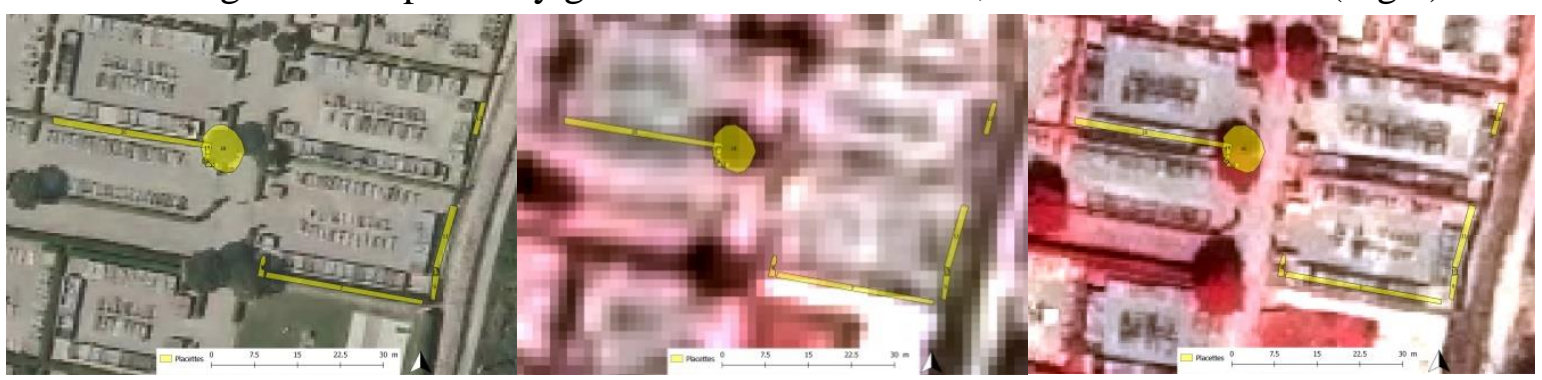

Figure 3 - Source images from left to right : Orthophoto 2011 IGN / Image Pléiades @ CNES 2017, Distribution Astrium Services / Spot Image S.A., France, tous droits réservés. Usage commercial interdit / SPOT 6 C) AIRBUS DS 2017 
We can observe correlations between GNDVI level and field score according to the type of vegetation in the wildland urban interface (Fig. 4).

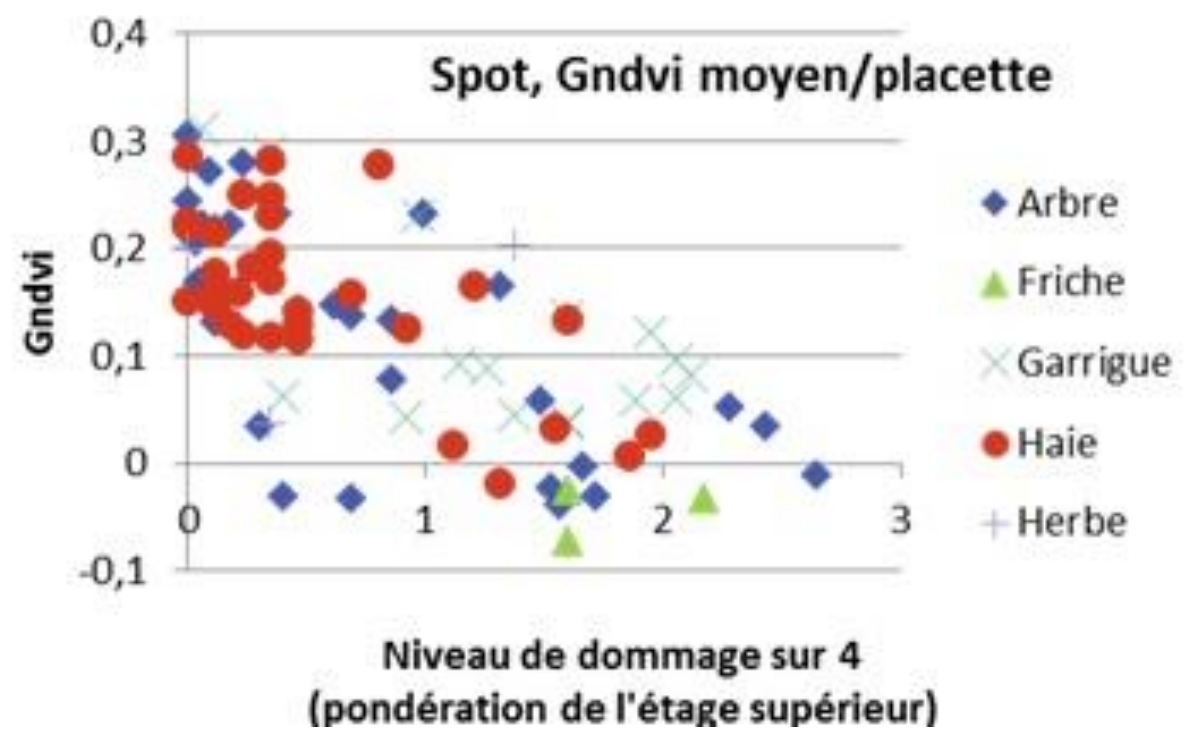

Figure 4 - relationship between Gndvi and field damage score 